\title{
Znaczenie minimalnej choroby resztkowej w szpiczaku plazmocytowym Stanowisko Polskiego Konsorcjum Szpiczakowego
}

\section{Current role of minimal residual disease in plasma cell myeloma: Position of Polish Myeloma Consortium}

Krzysztof Jamroziak ${ }^{1}$, Agnieszka Krzywdzińska ${ }^{2}$, Iwona Solarska ${ }^{3}$, Bartosz Puła ${ }^{1}$, Anna Czyż ${ }^{4,5}$, Tomasz Wróbel ${ }^{5}$, Krzysztof Giannopoulos ${ }^{6,7}$, Krzysztof Warzocha ${ }^{1}$, Dominik Dytfeld ${ }^{4}$

${ }^{1}$ Klinika Hematologii, Instytut Hematologii i Transfuzjologii, Warszawa

${ }^{2}$ Pracownia Immunofenotypowania, Zakład Diagnostyki Hematologicznej, Instytut Hematologii

i Transfuzjologii, Warszawa

${ }^{3}$ Pracownia Biologii Molekularnej, Zakład Diagnostyki Hematologicznej, Instytut Hematologii

i Transfuzjologii, Warszawa

${ }^{4}$ Katedra i Klinika Hematologii i Transplantacji Szpiku, Uniwersytet Medyczny

im. Karola Marcinkowskiego, Poznań

${ }^{5}$ Klinika Hematologii, Nowotworów Krwi i Transplantacji Szpiku, Samodzielny Publiczny Szpital Kliniczny, Uniwersytet Medyczny, Wrocław

${ }^{6}$ Oddział Hematologiczny, Centrum Onkologii Ziemi Lubelskiej im. św. Jana z Dukli, Lublin

${ }^{7}$ Zakład Hematoonkologii Doświadczalnej, Uniwersytet Medyczny, Lublin

\begin{abstract}
Streszczenie
Wprowadzenie do terapii chorych na szpiczaka plazmocytowego (PCM) znacznej liczby nowych leków pozwolito na poprawe gtębokości uzyskiwanych odpowiedzi, a w konsekwencji na wydtużenie okresu remisji i przeżycia chorych. Mimo wyższego obecnie odsetka catkowitych remisji (CR) u większości pacjentów dochodzi jednak do nawrotu choroby, co może być ttumaczone pozostawaniem po zakończeniu leczenia niewielkich populacji klonalnych plazmocytów w szpiku kostnym, określanych mianem minimalnej choroby resztkowej (MRD). Prognostyczne znaczenie wystepowania $M R D$ u chorych $w$ CR potwierdzono $w$ wielu badaniach klinicznych, a ocena MRD stata sie $w$ ostatnim czasie rutynowym narzędziem $w$ ocenie skuteczności najnowszych leków $i$ schematów terapii. Ponadto $w$ najnowszych kryteriach odpowiedzi IMWG (International Myeloma Working Group) z 2016 roku wprowadzono kategorie odpowiedzi oparte na badaniu MRD oznaczanej z czutościa co najmniej $10^{-5}$ najnowocześniejszymi technikami diagnostycznymi - cytometrii przeptywowej nowej generacji $i$ sekwencjonowania nowej generacji. W pracy podsumowano aktualne znaczenie oceny MRD u chorych na PCM, ze szczególnym uwzględnieniem metodyki oceny MRD technika cytometrii przeplywowej. W opinii Polskiego Konsorcjum Szpiczakowego upowszechnienie i standaryzacja oceny MRD w PCM może sie przyczynić do poprawy wyników leczenia chorych na ten nowotwór $w$ Polsce.
\end{abstract}

Słowa kluczowe: szpiczak plazmocytowy, minimalna choroba resztkowa, rokowanie

Hematologia 2017; 8, 4: 246-254

Adres do korespondencji: Krzysztof Jamroziak, Klinika Hematologii, Instytut Hematologii i Transfuzjologii, ul. Indiry Gandhi 14, 02-776 Warszawa, tel. +48 223496 478, faks +48 2234 96 335, e-mail: krzysztof.jamroziak@wp.pl 


\begin{abstract}
Introducing substantial numbers of new drugs in treatment armamentarium for plasma cell myeloma (PCM) has improved the depth and duration of achieved responses as well as prolongation of overall survival. Although complete responses (CR) are significantly more common with novel therapies, a majority of patients still relapse. This may be due to small populations of clonal plasma cells persisting after treatment; the phenomenon known as minimal residual disease (MRD). The prognostic role of MRD in patients with CR has been confirmed by numerous clinical trials, and recently $M R D$ assessment has become a routine tool for evaluating how effective the latest drugs and therapy protocols are. Furthermore, the updated response criteria of IMWG (International Myeloma Working Group) have included response categories based on MRD evaluation with modern techniques characterized by at least $10^{-5}$ sensitivity: i.e. next generation flow and next generation sequencing. In this paper, we discuss the current role of MRD in PCM, with particular emphasis on the methodology of assessing MRD by flow cytometry. In the opinion of the Polish Myeloma Consortium members, dissemination and standardization of MRD assessment in PCM may lead to improvement of PCM therapy in Poland.
\end{abstract}

\title{
Key words: plasma cell myeloma, minimal residual disease, prognosis
}

Hematologia 2017; 8, 4: 246-254

\section{Postęp w terapii szpiczaka plazmocytowego}

Szpiczak plazmocytowy (PCM, plasma cell myeloma) to jedna $\mathrm{z}$ najczęściej diagnozowanych chorób rozrostowych układu chłonnego. Według danych Krajowego Rejestru Nowotworów zachorowalność na nowotwory $z$ komórek plazmatycznych w Polsce w latach 2013-2014 wynosiła średnio 3,9/100 tys. mieszkańców, co daje około 1500 nowych rozpoznań rocznie [1]. Mediana wieku rozpoznania PCM mieści się w przedziale 65-70 lat, przy czym mniej niż $10 \%$ pacjentów stanowią osoby poniżej 50. roku życia.

Szpiczak plazmocytowy jest wynikiem proliferacji klonalnych komórek plazmatycznych wywodzących się $z$ opuszczających ośrodki rozmnażania limfocytów $\mathrm{B}$, które ulegają transformacji nowotworowej w wyniku zmian cytogenetycznych i molekularnych, zaburzających prawidłowe procesy apoptotyczne i interakcje mikrośrodowiskowe [2]. Według ostatnio przyjętych kryteriów do rozpoznania PCM wymaga się stwierdzenia 1) co najmniej $10 \%$ klonalnych komórek plazmatycznych w badaniu immunohistopatologicznym lub cytomorfologicznym szpiku albo występowania nacieku plazmocytowego w lokalizacji pozaszpikowej oraz 2) przynajmniej jednego ze ściśle zdefiniowanych objawów klinicznych lub laboratoryjnych świadczących o uszkodzeniu narządów [3]. Do uwzględnionych w tej definicji objawów klinicznych zalicza się podwyższone stężenie wapnia w surowicy, podwyższone stężenie kreatyniny w surowicy, niedokrwistość oraz zmiany osteolityczne (tzw. objawy CRAB [calcium elevation, renal insuficiency, anemia, bone changes]). Objawy laboratoryjne definiujące PCM obejmują natomiast naciek co najmniej $60 \%$ patologicznych plazmocytów w szpiku, stosunek wolnych łańcuchów lekkich powyżej 100 lub poniżej 0,01 oraz obecność co najmniej dwóch zmian ogniskowych stwierdzonych w badaniu metodą rezonansu magnetycznego (MRI, magnetic resonance imaging) [3, 4].

Szpiczak plazmocytowy należy do chorób nowotworowych, w odniesieniu do których dokonał się największy postęp terapeutyczny w ostatnich dwóch dekadach. Postęp ten wyraża się rejestracją znacznej liczby nowych leków, a jego konsekwencją jest wyraźna poprawa czasu i jakości życia chorych. Na początku XXI wieku wskaźnik 5-letnich przeżyć względnych u chorych na PCM w Polsce wynosił $28 \%$ [5]. Obecnie w populacji europejskiej wskaźnik 5-letniego przeżycia wynosi około 55\%, a prawdopodobieństwo przeżycia 10 lat - około $30 \%$ $[6,7]$. Poprawa rokowania jest wynikiem intensywnych badań nad patogenezą PCM i mechanizmami oporności na chemioterapię, które umożliwiły opracowanie i wprowadzenie do praktyki klinicznej nowych grup leków, w tym inhibitorów proteasomu, leków immunomodulujących, inhibitorów deacetylaz histonów i przeciwciał monoklonalnych. Złożone mechanizmy działania przeciwnowotworowego tych leków polegają między innymi na regulacji ekspresji genów indukujących apoptozę, hamowaniu 
angiogenezy, zaburzaniu interakcji między komórkami PCM a mikrośrodowiskiem szpiku i stymulowaniu odpowiedzi immunologicznej chorego na komórki szpiczaka [8-12].

\section{Ewolucja kryteriów odpowiedzi na leczenie PCM}

Wraz z rozwojem skuteczniejszych metod terapii modyfikacjom ulegał również sposób oceny odpowiedzi na leczenie PCM. W praktyce klinicznej podstawowymi parametrami stosowanymi do monitorowania aktywności terapii są stopień redukcji stężenia białka monoklonalnego (białka M) oraz stopień ograniczenia nacieku plazmocytowego w szpiku. Według stosowanych powszechnie kryteriów oceny odpowiedzi Europejskiego Towarzystwa Przeszczepiania Szpiku i Krwi (EBMT, European Society for Blood and Marrow Transplantation) całkowitą remisję (CR) osiągają pacjenci, u których są spełnione wszystkie następujące warunki: brak białka $\mathrm{M}$ w surowicy i moczu stwierdzony w 2-krotnie przeprowadzonym badaniu metodą immunofiksacji, mniej niż $5 \%$ komórek plazmatycznych w badaniu szpiku niezależnie od klonalności, brak guzów plasmocytoma w tkankach miękkich [13].

Osiągnięcie znacznego zmniejszenia masy nowotworu (czyli tzw. głębokiej odpowiedzi) stanowiło od dawna jeden $z$ istotnych celów terapii PCM. Jak wykazano w wielu badaniach klinicznych, uzyskanie CR koreluje z korzystnymi odległymi wynikami leczenia i jest niezależnym od wieku, rodzaju terapii czy stadium zaawansowania PCM czynnikiem predykcyjnym dłuższego czasu wolnego od progresji (PFS, progression-free survival) i przeżycia całkowitego (OS, overall survival) [14, 15]. Jednak w dobie konwencjonalnej chemioterapii odpowiedzi na poziomie CR uzyskiwano stosunkowo rzadko. Sytuacja ta zmieniła się wraz z rozwojem nowych metod terapii PCM. Nowoczesne strategie terapeutyczne, obejmujące schematy indukujące zawierające leki o różnych mechanizmach działania oraz konsolidację za pomocą dużych dawek melfalanu $z$ przeszczepieniem autologicznych krwiotwórczych komórek macierzystych (auto-HSCT, autologous hematopoetic stem cell transplantation), umożliwiły osiąnnięcie głębokich odpowiedzi nawet u $70 \%$ chorych, w tym znaczny odsetek CR $[16,17]$. $Z$ tych względów konieczne stało się zdefiniowanie kryteriów oceny odpowiedzi uwzględniających odpowiedzi ,głębsze” niż CR. Pierwszym krokiem $\mathrm{w}$ tym kierunku było wprowadzenie w 2006 roku przez Międzynarodową Grupę Roboczą ds. Szpicza- ka (IMWG, International Myeloma Working Group) kategorii rygorystycznej remisji całkowitej (sCR, stringent $C R$ ), która oprócz spełnienia warunków CR wymaga dodatkowo normalizacji stosunku wolnych łańcuchów lekkich (sFLC, serum free light chain) oraz braku klonalnych plazmocytów w szpiku w badaniu immunohistochemicznym lub immunofluorescencyjnym [18].

Mimo znacznie częstszego osiągania CR i sCR, u większości chorych dochodzi jednak do progresji i wznowy PCM. Nawroty u pacjentów w CR tłumaczy się pozostawaniem po zakończeniu leczenia niewielkich populacji plazmocytów, które przetrwały stosowaną chemioterapię, ale pozostają poniżej progu wykrywalności rutynowymi metodami diagnostycznymi [19, 20]. Udowodniono, że nawet u $35 \%$ pacjentów w CR komórki PCM są wykrywane metodą cytometrii przepływowej [21], natomiast badanie sFLC (służące do określenia odpowiedzi sCR) nie zawsze dostarcza dodatkowych informacji prognostycznych [22]. Wraz z rosnąca dostępnością coraz bardziej skutecznych terapii i rozwojem technik diagnostycznych kategorie odpowiedzi CR i sCR, ze względu na swoją ograniczoną czułość szacowaną na $10^{-2}-10^{-3}$, przestały więc być wystarczające.

$Z$ tych względów zaistniała potrzeba opracowania definicji nowych kategorii odpowiedzi, które umożliwiłyby ocenę ilościową choroby poniżej progu CR i sCR, czyli tak zwanej minimalnej choroby resztkowej (MRD, minimal residual disease). W rekomendacjach IMWG z 2011 roku po raz pierwszy zaproponowano dodatkowe kategoria odpowiedzi, oparte na badaniu MRD w szpiku kostnym immunofenotypową CR (immunophenotypic $C R$ ), określaną z zastosowaniem przynajmniej 4-kolorowej cytometrii przepływowej, oraz molekularną CR (molecular CR), oceniana metodą specyficznej dla allelu reakcji łańcuchowej polimerazy oligonukleotydu (ASO-PCR allele-specific oligonucleotide polymerase chain reaction) [23]. Techniki te umożliwiły oznaczanie MRD z czułością odpowiednio $10^{-4}$ i $10^{-5}$, co oznacza możliwość detekcji jednej komórki PCM wśród 10-100 tys. komórek szpiku [24, 25]. Badanie MRD stało się narzędziem w ocenie skuteczności najnowszych leków i schematów terapii, a prognostyczne znaczenie obecności resztkowych komórek PCM udowodniono w licznych publikacjach. Rawstron i wsp. [26] w badaniu obejmującym 397 pacjentów wykazali, że obecność MRD ponad $0,01 \%$, wykrywana 100 dni po auto-HSCT, istotnie wpływa na PFS $(15,5 v$. 28,6 mies.; $\mathrm{p}<0,001)$ i OS (59 v. 80,6 mies.; $\mathrm{p}=0,018$ ). Wpływ statusu MRD na czas przeżycia był również widoczny u chorych, 
Tabela 1. Kryteria oceny minimalnej choroby resztkowej (MRD) w szpiczaku plazmocytowym według Międzynarodowej Grupy Roboczej ds. Szpiczaka (źródło [33])

Table 1. Criteria of minimal residual disease (MRD) in plasma cell myeloma according to International Myeloma Working Group (source [33])

\begin{tabular}{ll}
\hline Utrzymująca się MRD(-) & $\begin{array}{l}\text { Brak MRD w szpiku kostnym (potwierdzony za pomocą NGF, NGS lub obiema metodami) } \\
\text { potwierdzony w kolejnym badaniu w odstępie } \geq 1 \text { roku }\end{array}$ \\
\hline MRD(-) badana za pomocą NGF & $\begin{array}{l}\text { Brak komórek plazmatycznych o aberrantnym immunofenotypie w aspiracie szpiku } \\
\text { kostnego stwierdzony za pomocą NGF, z wykorzystaniem procedury EuroFlow ozna- } \\
\text { czania MRD w szpiczaku plazmocytowym (lub zwalidowanej równoważnej procedury), } \\
\text { z minimalną czułością 10 } 10^{-5} \text { komórek jądrowych }\end{array}$ \\
\hline MRD(-) badana za pomocą NGS & $\begin{array}{l}\text { Brak komórek klonalnych w aspiracie szpiku kostnego stwierdzony za pomocą NGS, przy } \\
\text { czym obecność klonu jest definiowana jako obecność więcej niż dwóch identycznych }\end{array}$ \\
& $\begin{array}{l}\text { odczytów sekwencjonowania przeprowadzonego z wykorzystaniem platformy Lympho- } \\
\text { SIGHT (lub ekwiwalentnej procedury), z minimalną czułością 10 } 0^{-5} \text { komórek jądrowych }\end{array}$ \\
\hline $\begin{array}{l}\text { Choroba wyjściowo obecna } \\
\text { w badaniach obrazowych }\end{array}$ & $\begin{array}{l}\text { Nieobecność MRD potwierdzona za pomocą NGF lub NGS oraz zanik wszystkich } \\
\text { obszarów z podwyższonym wychwytem znacznika obserwowanym wyjściowo lub } \\
\text { podczas ostatniej oceny PET/CT albo obniżenie wychwytu poniżej wartości stwierdzonej }\end{array}$ \\
\hline
\end{tabular}

NGF (next generation flow) - cytometria przepływowa nowej generacji; NGS (next generation sequencing) - sekwencjonowanie nowej generacji; PET/CT (positron emission tomography/computed tomography) — pozytonowa tomografia emisyjna sprzężona z tomografią komputerową

którzy osiągnęli CR i pozostawał niezależny od ryzyka cytogenetycznego [26]. Podobne wyniki uzyskali Paiva i wsp. [27], dodatkowo sugerując, że wyjściowa ocena nieprawidłowości cytogenetycznych w połączeniu $z$ oceną odpowiedzi MRD po przeszczepieniu może pomóc $\mathrm{w}$ identyfikacji pacjentów w $\mathrm{CR}$ obciążonych wysokim ryzykiem wznowy, wymagających nowych strategii leczenia po auto-HSCT. $Z$ kolei Ferrero i wsp. [28] wskazali na przydatność monitorowania MRD po auto-HSCT w ocenie efektywności leczenia konsolidującego i podtrzymującego służącego uzyskaniu trwałych odpowiedzi. Znaczenie negatywizacji MRD potwierdzono także u chorych powyżej 65 . roku życia [29] oraz $\mathrm{w}$ leczeniu pacjentów $z$ nawrotem PCM [30]. U pacjentów w CR po chemioterapii ratunkowej status $\mathrm{MRD}(+)$, w porównaniu z $\mathrm{MRD}(-)$, wiązał się $z$ wysokim prawdopodobieństwem wznowy $\mathrm{w}$ ciągu roku, $\mathrm{z}$ medianą czasu do progresji (TTP, time to progression) wynoszącą $14 \mathrm{w}$ porównaniu z 75 miesiącami. Autorzy podkreślają ponadto, że ze względu na ryzyko wznowy pozaszpikowej, również u pacjentów MRD(-) po auto-HSCT, w kompleksowej ocenie odpowiedzi powinno się uwzględniać badania obrazowe metodą pozytonowej tomografii emisyjnej sprzężonej $z$ tomografią komputerową (PET/CT, positron emission tomography/computed tomography) [30].

Wraz z udoskonalaniem technik biologii molekularnej i cytometrii pojawiła się możliwość jeszcze bardziej czułej i specyficznej oceny obecności przetrwałych patologicznych plazmocytów, wzmacniającej znaczenie MRD jako czynnika prognostycznego [31]. Potwierdzili to w swoich pracach Martinez-Lopez i wsp. [32], którzy badając MRD z użyciem sekwencjonowania nowej generacji (NGS, next generation sequencing) $\mathrm{z}$ czulością ponad $10^{-5}$ - zaproponowali stratyfikację chorych według osiaganego poziomu MRD $\left(10^{-3}\right.$ v. $10^{-3}-10^{-5} v \cdot 10^{-5}$ ). Wykazano bowiem, że średni TTP istotnie się różnił między tymi grupami i wyniósł odpowiednio 27, 48 i 80 miesięcy [32].

W najnowszych kryteriach odpowiedzi na leczenie IMWG z 2016 roku wprowadziło kategorie oparte na badaniu MRD w aspiracie szpiku, oznaczanej z czułością co najmniej $10^{-5}$ za pomocą najnowocześniejszych technik diagnostycznych cytometrii przepływowej nowej generacji (NGF, next generation flow) i NGS (tab. 1) [33]. Po raz pierwszy również uwzględniono kryterium MRD oparte na badaniach obrazowych metodą PET/CT, umożliwiających monitorowanie pozaszpikowej postaci szpiczaka. Kategorie odpowiedzi, których podstawą jest badanie MRD, nie wymagają potwierdzenia wyniku oznaczenia $\mathrm{w}$ dodatkowym badaniu szpiku. Istotne jest natomiast, by temu badaniu poddawać materiał jak najlepszej jakości - minimum $2 \mathrm{ml}$ szpiku $\mathrm{z}$ pierwszej aspiracji, nie przekraczając przy tym objętości $4-5 \mathrm{ml}$ ze względu na możliwość rozcieńczenia krwią. Zaleca się, by testy MRD przeprowadzać po kolejnych etapach leczenia (po indukcji, auto-HSCT, konsolidacji, leczeniu podtrzymującym) tylko u chorych w CR [33]. 


\section{Ocena MRD metodą cytometrii przepływowej}

Najbardziej dostępną w warunkach klinicznych metodą oceny MRD u chorych na PCM wydaje się obecnie cytometria przepływowa [25]. Pozwala ona na identyfikację komórek na podstawie ich immunofenotypu, tj. ekspresji antygenów powierzchniowych i cytoplazmatycznych wykrywanych za pomocą swoistych przeciwciał. Choć metoda ta jest niezbędnym narzędziem w rozpoznawaniu, klasyfikacji i monitorowaniu chorób limfoproliferacyjnych i ostrych białaczek, to w przypadku gammapatii monoklonalnych dopiero niedawno zyskała szersze zastosowanie. W tym zakresie rolę cytometrii przepływowej upatruje się w diagnostyce różnicowej rozrostów $z$ komórek plazmatycznych, identyfikacji pacjentów $z$ gammapatią monoklonalną o nieokreślonym znaczeniu (MGUS, monoclonal gammapathy of undetermined significance) i szpiczakiem bezobjawowym obciążonym wysokim ryzykiem progresji oraz $\mathrm{w}$ monitorowaniu efektów terapii poprzez ocenę MRD [34, 35].

Cechami charakterystycznymi fenotypu prawidłowych komórek plazmatycznych są obecność antygenu CD138, wysoka ekspresja CD38 i słabsza w porównaniu $z$ limfocytami ekspresja CD45. Plazmocyty, jako komórki wywodzące się z linii limfocytów B, wykazują również ekspresję CD19, CD27 czy CD81. Zmiany w fenotypie plazmocytów, spowodowane transformacją nowotworową, mogą mieć charakter ilościowy, na przykład obniżenie lub zanik ekspresji CD19, CD27 czy CD45 oraz jakościowy, na przykład pojawienie się antygenu CD56 i CD117. Klonalny charakter komórek potwierdza cytoplazmatyczna ekspresja jednego $z$ łańcuchów lekkich kappa lub lambda [36]. Uzyskany w ten sposób nietypowy wzór antygenowy to tak zwany fenotyp aberrantny, umożliwiający wiarygodną, ilościową ocenę populacji komórek PCM wśród prawidłowych komórek szpiku.

Zważywszy na udowodnione znaczenie kliniczne i wartość prognostyczną poziomu MRD u chorych na szpiczaka oraz wprowadzenie kryterium MRD do kategorii odpowiedzi, grupa ekspertów Międzynarodowego Towarzystwa Cytometrii Klinicznej (ICCS, International Clinical Cytometry Society) i Europejskiego Towarzystwa Klinicznej Analizy Komórek (ESCCA, European Society for Clinical Cell Analysis) opracowała szczegółowe wytyczne dotyczące wymagań i sposobu przeprowadzenia tego badania metodą cytometryczną [37-40]. Obejmują one wszystkie aspekty decydujące o poprawności, specyficzności i czułości testu. Według najnowszych zaleceń odpowiednią specyficzność oznaczeń gwarantuje zastosowanie minimum 8-kolorowego panelu przeciwciał zawierającego: CD38, CD138, CD45, CD19, CD27, CD56, CD81, CD117, a dodatkowa analiza cytoplazmatycznych łańcuchów kappa i lambda pozwala potwierdzić klonalność podejrzanej subpopulacji plazmocytów. Wykazano, że w ten sposób można wychwycić fenotyp aberrantny i wiarygodnie monitorować MRD u ponad $97 \%$ pacjentów [38]. Taki zestaw przeciwciał pozwala również na identyfikację kilkunastu różnych subpopulacji leukocytów w badanym aspiracie szpiku, a wśród nich tych, które będą świadczyć o jego jakości (prekursory limfocytów B, mieloblasty, mastocyty, erytroblasty). Aby określić obecność lub brak komórek PCM na poziomie $0,001 \%\left(10^{-5}\right)$, konieczna jest akwizycja co najmniej 2 mln komórek szpiku, natomiast optymalna liczba komórek do oznaczeń ilościowych MRD to 5 mln komórek. Zastosowanie specjalnego protokołu przygotowania próbki do barwienia (pre-lysis) umożliwia zebranie odpowiedniej liczby zdarzeń bez konieczności zwiększania objętości potrzebnych przeciwciał [39]. Wynik badania MRD powinien zawierać następujące informacje: odsetek wszystkich plazmocytów w szpiku, odsetek komórek PCM wraz z fenotypem, czułość badania wyrażoną jako próg czułości (LOD, limit of detection) i/lub próg oznaczalności (LOQ, limit of quantification) [40].

Według najnowszych kryteriów odpowiedzi u chorego na PCM status MRD(-) oznacza brak komórek PCM w aspiracie szpiku odpowiedniej jakości, który zbadano $\mathrm{z}$ czułością co najmniej $10^{-5}$. Według IMWG metodą referencyjną dla takich oznaczeń jest NGF i w pełni zwalidowany protokół badania proponowany przez konsorcjum EuroFlow [33]. Nie tylko spełnia on wszystkie zalecenia ICCS/ESCCA, ale przede wszystkim standaryzuje sposób ustawienia cytometru, optymalizuje panel przeciwciał (w zakresie klonów i fluorochromów) oraz precyzuje sposób przygotowania próbki i akwizycji. Wszystkie te działania istotnie poprawiają specyficzność i powtarzalność badania, a użycie zaawansowanych narzędzi do analizy danych, w przyszłości prowadzących zapewne do automatyzacji oznaczeń, zwiększa próg detekcji populacji plazmocytów PCM do $10^{-6}$, zbliżając się tym samym do czułości osiąganej metodą NGS [41].

\section{Ocena MRD w projektach Polskiego Konsorcjum Szpiczakowego}

W dotychczasowych badaniach wykazano, że przeprowadzenie oceny MRD u chorych na 
PCM po zakończeniu określonych faz leczenia może dostarczyć wiarygodnych informacji prognostycznych. Monitorowanie MRD jest obecnie standardem we wszystkich badaniach klinicznych dotyczących PCM, a wkrótce prawdopodobnie będzie również parametrem branym pod uwagę przy rejestracji nowych leków. Chociaż w aktualnej rutynowej praktyce klinicznej wynik badania MRD ma przede wszystkim istotną wartość rokowniczą, to w bliskiej przyszłości może również służyć do indywidualizacji leczenia szpiczaka. Należy jednak podkreślić, że wiele zagadnień dotyczących badania MRD w PCM wymaga jeszcze optymalizacji, na przykład ustalenie najbardziej odpowiedniego progu czułości oraz optymalnych punktów czasowych.

W opinii członków Polskiego Konsorcjum Szpiczakowego (PMC, Polish Myeloma Consortium) wprowadzenie oceny MRD za pomocą cytometrii przepływowej jest jednym $z$ elementów, które mogą się przyczynić do poprawy wyników leczenia chorych na PCM. $Z$ tego względu PMC podjęło działania, których celem jest edukacja na temat znaczenia MRD u chorych na PCM, a także upowszechnienie i standaryzacja tego badania w Polsce. W celu analizy aktualnie stosowanej praktyki oceny MRD u chorych na PCM, dostępności niezbędnej aparatury i wykwalifikowanego personelu oraz planów dotyczących tego zagadnienia przeprowadzono badanie ankietowe obejmujące 15 polskich ośrodków hematologicznych. Wyniki tego badania podsumowano $\mathrm{w}$ artykule zawartym $\mathrm{w}$ niniejszym numerze „Hematologii” [42]. Ponadto 20 kwietnia 2017 roku we Wrocławiu, pod patronatem naukowym PMC, odbyły się warsztaty szkoleniowe pt. „Choroba resztkowa w szpiczaku plazmocytowym”, z udziałem wielu hematologów i cytometrystów z polskich ośrodków hematologicznych. Podczas tego spotkania międzynarodowi eksperci, między innymi profesor Roman Hajek (Klinika Hematologii Uniwersytetu w Ostrawie, Czechy), dr Lucie Rihova (Klinika Hematoonkologii Uniwersytetu w Brnie, Czechy) oraz profesor Joaquin Martinez-Lopez (Klinika Hematologii Uniwersytetu Complutense w Madrycie, Hiszpania), wygłosili wykłady na temat znaczenia i metodyki oceny MRD u chorych na PCM, w tym cytometrii i technik molekularnych, szczególnie NGS. Materiały szkoleniowe $z$ tych prezentacji są dostępne na stronie internetowej PMC (www.pmc.edu.pl). Po zakończeniu wykładów, podczas interesującej dyskusji, zwrócono uwagę na potrzebę standaryzacji oceny MRD w Polsce i opracowania odpowiednich wytycznych.

Mimo że rokownicze znaczenie MRD nie budzi wątpliwości, nie opracowano jeszcze zasad podejmowania decyzji terapeutycznych na podstawie wyniku oceny MRD, co wydaje się kolejnym logicznym etapem rozwoju terapii PCM. Polskie Konsorcjum Szpiczakowe przykłada dużą wagę do możliwości indywidualizacji leczenia na podstawie oceny MRD i projektuje badania kliniczne mające służyć temu celowi. W badaniu PMC006 (EudraCT 2015-002380-42), prowadzonym we współpracy z Uniwersytetem w Chicago, w którym porównuje się skuteczność i bezpieczeństwo leczenia podtrzymującego lenalidomidem po auto-HSCT ze skutecznością i bezpieczeństwem chemioterapii trójlekowej KRd (karfilzomib, lenalidomid, deksametazon), $z$ uwzględnieniem MRD zarówno jako celu terapii, jak i podstawy indywidualizacji leczenia. Status MRD jest oceniany co 6 miesięcy metodami cytometrii przepływowej oraz NGS, $z$ czułością co najmniej $10^{-5}$. Analiza ta posłuży do określenia odsetka pacjentów z nieobecną MRD $\mathrm{w}$ obu grupach. Co jednak istotniejsze, w badaniu zaplanowano modyfikację terapii uzależnioną od statusu MRD. U chorych cechujących się niskim ryzykiem cytogenetycznym leczonych chemioterapią KRd, u których po 6 cyklach leczenia podtrzymującego nie wykryto MRD ani w badaniu cytometrycznym, ani metodą NGS, terapia KRd będzie kontynuowana jeszcze przez dwa cykle, po czym chory zostanie poddany monoterapii lenalidomidem, jak w grupie kontrolnej, do 36 . cyklu lub progresji. Na podstawie dotychczasowych obserwacji szacuje się, że u co najmniej $60 \%$ pacjentów $z$ grupy badanej po 8 cyklach leczenia MRD będzie niewykrywalna $[43,44]$. Wyniki badania $z$ jednej strony będą ważnym głosem $\mathrm{w}$ dyskusji o znaczeniu oceny MRD jako punktu końcowego terapii (swego rodzaju surogatu PFS), a $z$ drugiej umożliwią dalsze prace nad terapią modyfikowaną zależnie od skuteczności leczenia ocenianej w badaniu MRD.

Celem kolejnego badania PMC008 „PRE-emptive DAratumumab Therapy Of minimal Residual disease reappearance or biochemical relapse in multiple myeloma (PREDATOR)" (EudraCT 2017-003253-41), które się rozpocznie w 2018 roku, będzie ocena leczenia wyprzedzającego (preemptywnego) wczesną progresję PCM pod postacią 1) pojawienia się MRD u chorych w CR $z$ niewykrywalną dotychczas MRD lub 2) wystąpienia bezobjawowego nawrotu biochemicznego [45]. Do części badania dotyczącej MRD zostanie włączonych 182 pacjentów, którzy uzyskali odpowiedź CR $\mathrm{MRD}(-)$ po maksymalnie dwóch liniach leczenia. W początkowej fazie obserwacyjnej badania chorzy będą monitorowani pod kątem konwersji do statusu $\mathrm{MRD}(+)$ za pomocą oceny MRD $\mathrm{w}$ aspiracie szpiku 
kostnego metodą cytometrii przepływowej $\mathrm{z}$ czułością co najmniej $10^{-5}$, wykonywanej regularnie co 4 miesiące. Następnie, w eksperymentalnej fazie badania, pierwszych 118 chorych, u których wystąpi konwersja do statusu MRD(+), przy jednoczesnym braku objawów progresji klinicznej PCM lub tak zwanego istotnego nawrotu biochemicznego (SPR, significant paraprotein relapse), zostanie poddanych randomizacji do leczenia daratumumabem lub do obserwacji. Wyniki tego badania mogą udowodnić, że wyprzedzające (preemptywne) leczenie na etapie pojawienia się MRD może doprowadzić do opóźnienia progresji klinicznej, a — być może - również poprawy rokowania w PCM. Leczenie wyprzedzające mogłoby również stanowić mniej toksyczną i bardziej ekonomiczną alternatywę dla leczenia podtrzymującego remisję stosowanego do progresji choroby.

\section{Podsumowanie}

Wprowadzenie do terapii nowych klas leków przyczyniło się do znaczącego wydłużenia czasu przeżycia chorych na PCM, a wstępne wyniki badań klinicznych nad najnowszymi schematami immunoterapii dają nadzieję na dalszy postęp rokowniczy [14, 46]. Poprawa jakości osiąganych odpowiedzi stała się również przyczyną ewolucji metod i kryteriów oceny odpowiedzi, $\mathrm{w}$ tym ostatniej aktualizacji wytycznych IMWG [33]. Wyniki badań z wykorzystaniem wieloparametrowej cytometrii przeplywowej i technik molekularnych (ASO-PCR, NGS), pozwalających na wykrywanie klonalnych plazmocytów $z$ czułością $10^{-4}-10^{-6}$, jednoznaczne wskazują, że MRD istotnie koreluje ze wskaźnikami przeżycia chorych, niezależnie od rodzaju zastosowanej chemioterapii, wieku pacjenta czy stadium choroby [47]. Ponadto autorzy nowych kryteriów IMWG, uwzgledniających ocenę MRD z czułością nie mniejszą niż $10^{-5}$, wskazują na celowość dążenia do eradykacji MRD i konieczność wprowadzenia czułych metod monitorowania w referencyjnych ośrodkach hematologicznych. Autorzy niniejszego stanowiska wyrażają nadzieję, że działania Polskiego Konsorcjum Szpiczakowego, zmierzające do upowszechnienia i standaryzacji oceny MRD u chorych na PCM, przyczynią się do poprawy wyników leczenia tych chorych w Polsce.

\section{Piśmiennictwo}

1. Wojciechowska U., Didkowska J. Zachorowania i zgony na nowotwory złośliwe w Polsce. 2017. http://onkologia.org.pl/raporty (14/03/2017).
2. Palumbo A, Anderson K. Multiple myeloma. N Engl J Med. 2011; 364(11): 1046-1060, doi: 10.1056/NEJMra1011442, indexed in Pubmed: 21410373.

3. Rajkumar SV, Dimopoulos MA, Palumbo A, et al. International Myeloma Working Group updated criteria for the diagnosis of multiple myeloma. Lancet Oncol. 2014; 15(12): e538-e548, doi: 10.1016/S1470-2045(14)70442-5, indexed in Pubmed: 25439696.

4. Dmoszyńska A, Usnarska-Zubkiewicz L, Walewski J, et al. Zalecenia Polskiej Grupy Szpiczakowej dotyczące rozpoznawania i leczenia szpiczaka plazmocytowego oraz innych dyskrazji plazmocytowych na rok 2017. Acta Haematol Pol. 2017; 48(2): 55-103, doi: 10.1016/j.achaem.2017.05.003.

5. Didkowska J., Wojciechowska U., Zatoński W. Wskaźniki przeżyć chorych na nowotwory złośliwe w Polsce zdiagnozowanych w latach 2000-2002. 2009. http://onkologia.org.pl/publikacje (14/03/2017).

6. Pulte D, Jansen L, Castro FA, et al. GEKID Cancer Survival Working Group. Trends in survival of multiple myeloma patients in Germany and the United States in the first decade of the $21^{\text {st }}$ century. Br J Haematol. 2015; 171(2): 189-196, doi: 10.1111/ /bjh.13537, indexed in Pubmed: 26123295.

7. Pulte D, Redaniel MT, Lowry L, et al. Age disparities in survival from lymphoma and myeloma: a comparison between US and England. Br J Haematol. 2014; 165(6): 824-831, doi: 10.1111/ /bjh.12837, indexed in Pubmed: 24684252.

8. Kubiczkova L, Pour L, Sedlarikova L, et al. Proteasome inhibitors - molecular basis and current perspectives in multiple myeloma. J Cell Mol Med. 2014; 18(6): 947-961, doi: 10.1111/jcmm.12279, indexed in Pubmed: 24712303.

9. Quach H, Ritchie D, Stewart AK, et al. Mechanism of action of immunomodulatory drugs (IMiDS) in multiple myeloma. Leukemia. 2010; 24(1): 22-32, doi: 10.1038/leu.2009.236, indexed in Pubmed: 19907437.

10. Sanchez L, Wang Y, Siegel DS, et al. Daratumumab: a first-inclass CD38 monoclonal antibody for the treatment of multiple myeloma. J Hematol Oncol. 2016; 9(1): 51, doi: 10.1186/s13045016-0283-0, indexed in Pubmed: 27363983.

11. Grabarska A, Dmoszyńska-Graniczka M, Nowosadzka E, et al. [Histone deacetylase inhibitors - molecular mechanisms of actions and clinical applications]. Postepy Hig Med Dosw (Online). 2013; 67: 722-735, doi: 10.5604/17322693.1061381, indexed in Pubmed: 24018438.

12. Salomon-Perzyński A, Jamroziak K. The role of daratumumab in the treatment of relapsed/refractory plasma cell myeloma. Hematol. 2017; 8(4): 255-264, doi: 10.5603/Hem.2017.0037.

13. Bladé J, Samson D, Reece D, et al. Criteria for evaluating disease response and progression in patients with multiple myeloma treated by high-dose therapy and haemopoietic stem cell transplantation. Myeloma Subcommittee of the EBMT. European Group for Blood and Marrow Transplant. Br J Haematol. 1998; 102(5): 1115-1123, doi: 10.1046/j.1365-2141.1998.00930.x, indexed in Pubmed: 9753033.

14. Chanan-Khan AA, Giralt S. Importance of achieving a complete response in multiple myeloma, and the impact of novel agents. J Clin Oncol. 2010; 28(15): 2612-2624, doi: 10.1200/ /JCO.2009.25.4250, indexed in Pubmed: 20385994.

15. Gay F, Larocca A, Wijermans P, et al. Complete response correlates with long-term progression-free and overall survival in elderly myeloma treated with novel agents: analysis of 1175 patients. Blood. 2011; 117(11): 3025-3031, doi: 10.1182/ /blood-2010-09-307645, indexed in Pubmed: 21228328. 
16. Jakubowiak AJ, Dytfeld D, Griffith KA, et al. A phase $1 / 2$ study of carfilzomib in combination with lenalidomide and low-dose dexamethasone as a frontline treatment for multiple myeloma. Blood. 2012; 120(9): 1801-1809, doi: 10.1182/blood-2012-04-422683, indexed in Pubmed: 22665938.

17. Kumar S, Flinn I, Richardson PG, et al. Randomized, multicenter, phase 2 study (EVOLUTION) of combinations of bortezomib, dexamethasone, cyclophosphamide, and lenalidomide in previously untreated multiple myeloma. Blood. 2012; 119(19): 4375-4382, doi: 10.1182/blood-2011-11-395749, indexed in Pubmed: 22422823 .

18. Durie BGM, Harousseau JL, Miguel JS, et al. International Myeloma Working Group. International uniform response criteria for multiple myeloma. Leukemia. 2006; 20(9): 1467-1473, doi: 10.1038/sj.leu.2404284, indexed in Pubmed: 16855634.

19. Shain KH, Dalton WS. Environmental-mediated drug resistance: a target for multiple myeloma therapy. Expert Rev Hematol. 2009; 2(6): 649-662, doi: 10.1586/ehm.09.55, indexed in Pubmed: 21082957.

20. Hajek R, Okubote SA, Svachova H. Myeloma stem cell concepts, heterogeneity and plasticity of multiple myeloma. $\mathrm{Br} \mathrm{J}$ Haematol. 2013; 163(5): 551-564, doi: 10.1111/bjh.12563, indexed in Pubmed: 24111932 .

21. Paiva B, Vidriales MB, Cerveró J, et al. GEM (Grupo Español de MM)/PETHEMA (Programa para el Estudio de la Terapéutica en Hemopatías Malignas) Cooperative Study Groups. Multiparameter flow cytometric remission is the most relevant prognostic factor for multiple myeloma patients who undergo autologous stem cell transplantation. Blood. 2008; 112(10): 4017-4023, doi: 10.1182/blood-2008-05-159624, indexed in Pubmed: 18669875 .

22. Martínez-López J, Paiva B, López-Anglada L, et al. Spanish Multiple Myeloma Group/Program for the Study of Malignant Blood Diseases Therapeutics (GEM/PETHEMA) Cooperative Study Group. Critical analysis of the stringent complete response in multiple myeloma: contribution of $\mathrm{SFLC}$ and bone marrow clonality. Blood. 2015; 126(7): 858-862, doi: 10.1182/ /blood-2015-04-638742, indexed in Pubmed: 26089396.

23. Rajkumar SV, Harousseau JL, Durie B, et al. International Myeloma Workshop Consensus Panel 1. Consensus recommendations for the uniform reporting of clinical trials: report of the International Myeloma Workshop Consensus Panel 1. Blood. 2011; 117(18): 4691-4695, doi: 10.1182/blood-2010-10-299487, indexed in Pubmed: 21292775.

24. Sanchez-Vega B, Ayala R, Cedena T, et al. Minimal residual disease testing for multiple myeloma. Hematol. 2017; 8(3): 219-227.

25. Rihova L, Hajek R. Flow cytometric minimal residual disease assessment in multiple myeloma. Hematol. 2017; 8(3): 211-218.

26. Rawstron AC, Child JA, de Tute RM, et al. Minimal residual disease assessed by multiparameter flow cytometry in multiple myeloma: impact on outcome in the Medical Research Council Myeloma IX Study. J Clin Oncol. 2013; 31(20): 2540-2547, doi: 10.1200/JCO.2012.46.2119, indexed in Pubmed: 23733781.

27. Paiva B, Gutiérrez NC, Rosiñol L, et al. PETHEMA/GEM (Programa para el Estudio de la Terapéutica en Hemopatías Malignas/Grupo Español de Mieloma) Cooperative Study Groups. High-risk cytogenetics and persistent minimal residual disease by multiparameter flow cytometry predict unsustained complete response after autologous stem cell transplantation in multiple myeloma. Blood. 2012; 119(3): 687-691, doi: 10.1182/ /blood-2011-07-370460, indexed in Pubmed: 22128143.
28. Ferrero S, Ladetto M, Drandi D, et al. Long-term results of the GIMEMA VEL-03-096 trial in MM patients receiving VTD consolidation after ASCT: MRD kinetics' impact on survival. Leukemia. 2015; 29(3): 689-695, doi: 10.1038/leu.2014.219, indexed in Pubmed: 25027515.

29. Paiva B, Martinez-Lopez J, Vidriales MB, et al. Comparison of immunofixation, serum free light chain, and immunophenotyping for response evaluation and prognostication in multiple myeloma. J Clin Oncol. 2011; 29(12): 1627-1633, doi: 10.1200/ /JC0.2010.33.1967, indexed in Pubmed: 21402611.

30. Paiva B, Chandia M, Puig N, et al. The prognostic value of multiparameter flow cytometry minimal residual disease assessment in relapsed multiple myeloma. Haematologica. 2015; 100(2): e53-e55, doi: 10.3324/haematol.2014.115162, indexed in Pubmed: 25381128 .

31. Rawstron AC, Gregory WM, de Tute RM, et al. Minimal residual disease in myeloma by flow cytometry: independent prediction of survival benefit per log reduction. Blood. 2015; 125(12): 1932-1935, doi: 10.1182/blood-2014-07-590166, indexed in Pubmed: 25645353.

32. Martinez-Lopez J, Lahuerta JJ, Pepin F, et al. Prognostic value of deep sequencing method for minimal residual disease detection in multiple myeloma. Blood. 2014; 123(20): 3073-3079, doi: 10.1182/ /blood-2014-01-550020, indexed in Pubmed: 24646471.

33. Kumar S, Paiva B, Anderson KC, et al. International Myeloma Working Group consensus criteria for response and minimal residual disease assessment in multiple myeloma. Lancet Oncol. 2016; 17(8): e328-e346, doi: 10.1016/S1470-2045(16)30206-6, indexed in Pubmed: 27511158.

34. Rawstron AC, Orfao A, Beksac M, et al. European Myeloma Network. Report of the European Myeloma Network on multiparametric flow cytometry in multiple myeloma and related disorders. Haematologica. 2008; 93(3): 431-438, doi: 10.3324/ /haematol.11080, indexed in Pubmed: 18268286.

35. Paiva B, Almeida J, Pérez-Andrés M, et al. Utility of flow cytometry immunophenotyping in multiple myeloma and other clonal plasma cell-related disorders. Cytometry B Clin Cytom. 2010; 78(4): 239-252, doi: 10.1002/cyto.b.20512, indexed in Pubmed: 20155853.

36. Raja KRM, Kovarova L, Hajek R. Review of phenotypic markers used in flow cytometric analysis of MGUS and MM, and applicability of flow cytometry in other plasma cell disorders. Br J Haematol. 2010; 149(3): 334-351, doi: 10.1111/j.13652141.2010.08121.x, indexed in Pubmed: 20201947.

37. Oldaker TA, Wallace PK, Barnett D. Flow cytometry quality requirements for monitoring of minimal disease in plasma cell myeloma. Cytometry B Clin Cytom. 2016; 90(1): 40-46, doi: 10.1002/ /cyto.b.21276, indexed in Pubmed: 26201282.

38. Flores-Montero J, de Tute R, Paiva B, et al. Immunophenotype of normal vs. myeloma plasma cells: Toward antibody panel specifications for MRD detection in multiple myeloma. Cytometry B Clin Cytom. 2016; 90(1): 61-72, doi: 10.1002/cyto.b.21265, indexed in Pubmed: 26100534.

39. Stetler-Stevenson M, Paiva B, Stoolman L, et al. Consensus guidelines for myeloma minimal residual disease sample staining and data acquisition. Cytometry B Clin Cytom. 2016; 90(1): 26-30, doi: 10.1002/cyto.b.21249, indexed in Pubmed: 25907102.

40. Arroz M, Came N, Lin P, et al. Consensus guidelines on plasma cell myeloma minimal residual disease analysis and reporting. Cytometry B Clin Cytom. 2016; 90(1): 31-39, doi: 10.1002/ /cyto.b.21228, indexed in Pubmed: 25619868. 


\section{Hematologia 2017, tom 8, nr 4}

41. Flores-Montero J, Sanoja-Flores L, Paiva B, et al. Next Generation Flow for highly sensitive and standardized detection of minimal residual disease in multiple myeloma. Leukemia. 2017; 31(10): 2094-2103, doi: 10.1038/leu.2017.29, indexed in Pubmed: 28104919 .

42. Krzywdzińska A, Solarska I, Puła B, et al. Minimal residual disease assessment in plasma cell myeloma patients in Poland: survey of the Polish Myeloma Consortium. Hematol. 2017; 8(4): 239-245, doi: 10.5603/Hem.2017.0035.

43. Zimmerman T, Raje NS, Vij R, et al. Final results of a phase 2 trial of extended treatment (tx) with carfilzomib (CFZ), lenalidomide (LEN), and dexamethasone (KRd) plus autologous stem cell transplantation (ASCT) in newly diagnosed multiple myeloma (NDMM). Blood. 2016; 128(22): 675.

44. Jakubowiak AJ, Raje N, Vij R, et al. High rate of sustained minimal residual disease negativity predicts prolonged survival for the overall patient population in the phase $2 \mathrm{KRd}$ plus autologous stem cell transplantation MMRC trial. Blood. 2017; 130(Suppl 1): 4533.

45. Jamroziak K, Giannopoulos K, Wrobel T, et al. Preemptive daratumumab therapy for minimal residual disease reappearance or biochemical relapse in multiple myeloma: rationale and design of the polish myeloma consortium predator study. Blood. 2017; 130(Suppl 1): 5404

46. Dimopoulos MA, Oriol A, Nahi H, et al. POLLUX Investigators Daratumumab, lenalidomide, and dexamethasone for multiple myeloma. N Engl J Med. 2016; 375(14): 1319-1331, doi: 10.1056/ NEJMoa1607751, indexed in Pubmed: 27705267.

47. Nishihori T, Song J, Shain KH. Minimal residual disease assessment in the context of multiple myeloma treatment. Curr Hematol Malig Rep. 2016; 11(2): 118-126, doi: 10.1007/s11899-0160308-3, indexed in Pubmed: 26898557. 